\title{
Location Determinants of Japanese Multinationals in Poland: Do Special Economic Zones Really Matter for Investment Decisions?
}

\author{
Andrzej Cieślik \\ Warsaw University \\ Michael Ryan \\ Western Michigan University
}

\begin{abstract}
We investigate the location determinants of Japanese multinationals in Poland using a regional data set from 1991 to 2001. Special attention is placed on the geographically targeted investment incentives (Special Economic Zones, SEZs) that were created during this period. Controlling for a more comprehensive set of region-specific characteristics than previously employed to evaluate SEZ importance, we find that our results are broadly consistent with previous FDI location choice studies. However, unlike other studies, the SEZ measure's statistical significance disappears when we control for a number of additional regional characteristics.
\end{abstract}

- JEL Classifications: F23, P33

- Key words: Japanese multinationals, Location choice, Poland, Special Economic Zones

\footnotetext{
*Corresponding address: Andrzej Cieślik, Macroeconomics and International Trade Theory Division Department of Economics, Warsaw University ul. Dluga 44/50, Warszawa, PL-00241, Poland, Tel: +4822-831-4725, Fax: +48-22-831-2846, E-mail: cieslik@coin.wne.uw.edu.pl. Michael Ryan, Department of Economics. Western Michigan University, 1903 W. Michigan Ave., Kalamazoo, MI-49008, USA, Tel: +1-269-387-5545, Fax: +1-269-387-5637, E-mail: michael.ryan@wmich.edu (2)005-Center for International Economics, Sejong Institution, All Rights Reserved.
} 


\section{Introduction}

In recent years Poland has emerged as one of the most popular FDI destinations (A.T. Kearney, 2003). Since the beginning of the political and economic transition in 1989, Poland has attracted over $\$ 72$ billion in foreign direct investment (FDI) and became the largest recipient of FDI in Central and Eastern Europe ${ }^{1}$ (PAIZ, 2004). The sustained inflow of foreign capital that followed Polish economic reforms creates a natural testing ground for the investigation of factors that influence multinational firms' location decisions, especially for investment into successful transforming economies that have recently joined the European Union.

Although there is a substantial literature on FDI into Central and Eastern European (CEE) countries, most studies concentrate on investment by Western multinational enterprises (MNEs) into groups of recipient countries rather than individual locations. ${ }^{2}$ In addition, while there is a well-established literature on Japanese direct investment into the EU-15 both at the country- and EU-15 level, there is very little evidence on Japanese investment into the countries that joined the EU in May 2004, of which Poland is the largest (in terms of area, population, and GDP). In fact, little attention has been devoted to FDI into the CEEs coming from individual Asian countries, with the notable exception being Cieślik and Ryan (2002) who characterize the broad pattern of Japanese direct investment in the region. However, although the Cieślik and Ryan (2002) study provides some stylized facts and investment characteristics, the authors do not say much about the determinants of Japanese FDI into the region.

Moreover, most studies on FDI into transition countries ignore completely the spatial aspects of multinational firms' activity. The few studies devoted to this topic that can be found in geography literature are mostly descriptive, do not have clear theoretical underpinnings, and reach conclusions that are not based on any formal statistical tests. Thus, the aim of this article is twofold. First, using the new economic geography literature as our guide, we empirically investigate the determinants of the spatial distribution of Japanese firms in Poland. Second, we contribute to the debate on the effectiveness of special economic zones in attracting foreign investment into the transitioning countries.

\footnotetext{
1“FDI Trend Reversed". Polish Agency for Foreign Investment (PAIZ) April 15, 2004 http://www. paiz.gov.pl/oldpaiz/.

${ }^{2}$ See, for example, Holland, et al. (2001), Mayer and Disdier (2003), Carstensen and Toubal (2003), and Cieślik and Ryan (2004).
} 
Compared to previous work, this article takes a narrow perspective and concentrates on one representative Asian FDI-source country - Japan, one of the most important FDI source countries in the world- and one CEE FDI-host country - Poland, the largest FDI-recipient country in CEEs. Thus, our study complements previous work on Japanese FDI into the CEEs while also contributing to the debate on the effectiveness of granting tax incentives to attract multinational firms.

Empirical evidence for developed economies shows that tax incentives have only a marginal impact on the location of foreign investment (Wells 1986, Mintz 1990, Devereux and Griffith 1998, Head et al. 1999). More frequently, it is stressed that the geographic concentration of foreign economic activity may result from various types of agglomeration economies, access to modern infrastructure networks, availability of specialized skills (human capital), and other factors that affect firm location decisions (Fujita and Thisse, 2002). However, a group of studies on investment into developing economies presents a contrary view of the effect of tax incentives (e.g., Head and Ries 1996, Cheng and Kwan 2000, Fung et al. 2002). ${ }^{3}$ A unifying theme among these studies is the focus placed on the determinants of inward Chinese FDI and the result that "special economic zones" (SEZs) are an effective policy instrument for attracting multinational firms to targeted regions. In fact, in assuming that SEZs are effective policy instruments, Schweinberger (2003) investigates other policies that should complement the establishment of these zones.

In our view, the conflicting results between the two groups of studies can partially be resolved by the data limitations faced by the developing country studies. In many cases, such studies rely on imperfect proxies for the extent of state aid (tax incentives) such as dummy variables to indicate the presence of SEZs in a particular region. At the same time, these studies are not able to accurately control for a number of the region-specific characteristics that pertain to each SEZ. By limiting the number and type of region-specific characteristics in the empirical estimation, potentially biased estimation results are achieved, since the SEZ dummy variable controls for all of the region-specific characteristics not individually included. Thus, policy conclusions as to the importance of SEZs on attracting inward FDI may be quite inaccurate.

This study focuses on determining the empirical robustness of the SEZ literature by examining how a different country's SEZ program has worked in attracting

${ }^{3}$ In addition, see also Makabenta (2002) on FDI into the Philippines. 
inward FDI. In choosing Poland as the FDI-host, we choose a country that parallels China in terms of its increasing significance in serving as an important FDI host. In addition, FDI into each country is designed to service both the domestic and geographically regional markets. Finally, Japanese FDI into both countries is quite significant. In fact, Poland received more inward Japanese FDI than 8 of the EU-15 countries during the $1990 \mathrm{~s}^{4}$; additionally, numerous previously established Japanese affiliates in the "old" European Union have relocated (or are planning to relocate) portions of their production to Poland. - "[Japanese] companies with manufacturing facilities [in Europe] are looking for lower cost areas [to produce] ...Central Europe is of particular interest."

A significant difference between the two countries, however, is that Poland has collected a wealth of additional region-specific characteristics that were unavailable for the China studies. While characteristics such as regional GDP, wages, and the type/amount of transportation infrastructure are typically examined, excluded from this list are variables such as other infrastructure types (e.g. telecommunications infrastructure)and various types of agglomeration externalities. As important inward-FDI determinants, including these additional FDI determinants into the empirical analysis allows for a better determination of the true impact of SEZs on FDI. In fact, when we combine Japanese firm-level FDI data with Polish regional characteristics for the period 1991-2001 to evaluate the determinants of Japanese FDI into Poland, our results are broadly consistent with previous FDI location choice studies.

However, when the set of regional characteristics is increased to include those determinants not previously examined, we find that SEZs do not play a significant role in attracting FDI. As a result, we argue that the findings of these studies cannot be considered convincing, as the statistical significance of such variables is not robust with respect to empirical specification of the estimating equation. Given the assembled evidence, we conclude that there is an obvious need to develop better methods of measuring the extent of regional state aid for multinational firms since analysis based on SEZ dummy variables and limited and incomplete sets of regional characteristics cannot provide accurate policy recommendations.

\footnotetext{
${ }^{4}$ This list includes Austria, Denmark, Finland, Greece, Ireland, Luxembourg, Portugal, and Sweden. In addition, Poland has received more Japanese FDI than all three EFTA countries (Iceland, Norway, Switzerland) as well.

${ }^{5}$ Interview with Koicho Akatsu, general director of JETRO Warsaw. Warsaw Voice (December 16, 2001). http://www.warsawvoice.pl/v686/Business06.html.
} 
The structure of this article is as follows. In the next section we describe analytical framework and statistical methodology. In Section 3 we discuss the spatial pattern of Japanese multinational activity in Poland and explanatory variables. In section 4 we present estimation results and in section 5 we conclude.

\section{Analytical Framework and Statistical Methodology}

While interest in studying the geographic concentration of economic activity dates back to Marshall's (1921) identification of various agglomeration economies, empirical studies of location determinants (especially formal statistical tests based on microeconomic data) have a only relatively short history. ${ }^{6}$ The first attempt to model optimal location selection using discrete choice models was made by Carlton (1983) who found that agglomeration economies played an important role in location decisions across U.S. metropolitan areas. Additional studies based on more extensive data sets (such as Bartik [1985] and Luger and Shetty [1985]) corroborated Carlton's (1983) initial conclusions. These early tests did not include any formal theory, however, imposing serious limitations on the interpretation of their empirical results and their usefulness for economic policy design.

The situation changed radically in the early 1990s with the emergence of the "new economic geography" strand of international economics literature. This strand was initiated by theoretical studies of Krugman (1991a, b), although similar issues were raised earlier by Abdel-Rahman (1988, 1990), Fujita (1988), and Rivera-Batiz (1988) in the urban economics literature. Combined, these seminal works enabled a better understanding of the spatial concentration of economic activity and triggered a new wave of empirical research on firm location decisions.

Krugman $(1996,1998)$ surveys centripetal and centrifugal forces that affect the location of economic activity in space. Centripetal forces include traditional natural advantages of particular locations such as harbors or central locations, market-size external economies related to demand and supply linkages or thick labor markets, and pure external economies like knowledge spillovers. Centrifugal forces comprise market-mediated forces like input costs as well as non-market forces

\footnotetext{
${ }^{6}$ While there is well-developed New-Trade-Multinational literature that explains the location of foreign firms (and various types of FDI) and its impact on international trade across countries (e.g., Markusen (2002)), it provides no special framework for explaining foreign investment in a regional context (i.e., across different regions of the same country). As a result, we refer to the regional economics literature for this framework.
} 
such as congestion or pollution.

While all the above forces may potentially impact firm location decisions, their magnitude differs greatly across empirical studies. For example, early survey evidence quoted in Glickman and Woodward (1988) and Friedman et al. (1992) suggests that market proximity, labor market conditions, and public capital are the most important FDI determinants. More recent econometric studies such as Guimarães et al. (2000) argue that foreign firms favor locations with a large amount of existing economic activity because such areas offer well-developed infrastructure, large markets, transportation facilities, and agglomeration economies. $^{7}$

Depending on the properties of the dataset, various modeling approaches and econometric procedures have been used for studying FDI determinants. In the empirical FDI literature OLS, logit, Tobit, Poisson and negative binomial techniques have been extensively employed. Our dependent variable $y_{i t}$, used as a measure of foreign involvement in the statistical analysis, is the number of Japanese firms observed in region $i$ at time $t{ }^{8}$ This variable assumes nonnegative integer values. The preponderance of zeros and small values in the sample, as well as the clearly discrete nature of the dependent variable, suggest that we can improve on traditional techniques with a specification that accounts for these characteristics. Thus, in this study, the use of count models (Poisson, negative binomial) appears to be the most suitable choice.

The Poisson regression model assumes that the number of firms $y_{i}$ observed in region $i$ is drawn from a Poisson distribution with the parameter $\lambda_{i}$ related to the independent variables vector $x_{i}$ that represents a set of regional characteristics. The probability of observing a count of foreign firms $\mathrm{y}_{\mathrm{i}}$ in region $i$ is expressed as:

$$
\operatorname{Pr}\left(y_{i} \mid x_{i}\right)=\frac{e^{-\lambda i} \lambda^{y i}}{Y_{i} !}, y_{i}=0,1,2, \ldots,
$$

where $\lambda_{i}$ is assumed to be log-linearly dependent on the vector of explanatory variables $x_{i}$ :

\footnotetext{
${ }^{7}$ In addition, see Head, et al.'s (1995) study on the location of Japanese manufacturing in U.S. states, Basile's (2002) study on the location choice of foreign manufacturers in Italy, and Carrod's (2002) study on the determinants of industrial location in Catalan municipalities.

${ }^{8} \mathrm{We}$ focus on the number of investments, rather than the capital stock, as the number of investments listed in Japanese (Toyo Keizai) and Polish (Polish Central Statistical Office) datasets is nearly identical. However, the capital stocks reported in these datasets vary considerably. Therefore, we choose the more consistent representation of Japanese FDI into Poland.
} 


$$
\ln \lambda_{i}=\beta^{\prime} x_{i}
$$

and $\beta$ is a parameter vector on exogenous variables that needs to be estimated.

The key assumption of the Poisson model is the equality of the first two moments:

$$
E\left[y_{i} \mid x_{i}\right]=\operatorname{var}\left[y_{i} \mid x_{i}\right]=\lambda_{i}
$$

This assumption is not very convenient since count data can exhibit overdispersion (where the conditional variance exceeds the mean). To overcome this potential problem, a negative binomial model is often used. The negative binomial model, a generalized version of the Poisson model, allows for multiplicative unobserved heterogeneity into the conditional mean:

$$
\ln \lambda_{i}=\beta^{\prime} x_{i}+\varepsilon_{i}
$$

where $\exp \left(\varepsilon_{\mathrm{i}}\right)$ has a gamma distribution with a mean of 1 and variance $\alpha$.

The expected value of $y_{i}$ in the negative binomial model is exactly the same as in the Poisson model; however, the variance differs and exceeds the mean:

$$
\operatorname{var}\left[y_{i} \mid x_{i}\right]=E\left[y_{i} \mid x_{i}\right]\left\{1+a E\left[y_{i} \mid x_{i}\right]\right\}
$$

A convenient feature of the negative binomial model is that the Poisson model is nested within it and a standard likelihood ratio test can be used to compare these two models. When the estimated parameter $\alpha$ is not statistically different from zero, the conditional mean equals the conditional variance, and the negative binomial model reduces to the Poisson model.

\section{Data and Explanatory Variables}

To estimate the count models discussed in the previous section, we require two sets of data: (1) firm level data on location choices of Japanese firms within Poland and (2) data on Polish regional characteristics.

The FDI data employed in this study is compiled from Toyo Keizai Inc.'s Japanese Overseas Investment: A complete listing by firms and countries (JOI), while regional characteristics data is culled from the various issues of Regional 
Statistical Yearbook (Rocznik Statystyczny Województw) published regularly the Polish Central Statistical Office (CSO) in Warsaw. ${ }^{9}$

For this study, an investment is considered only if (1) it occurred in one of 16 Polish regions during the period 1991-2001; and (2) if the principle Japanese investor held an equity ownership share of at least 10 per cent. ${ }^{10}$ For each individual investment, the JOI provides detailed information on numerous aspects of the affiliate and the investing parents, including: the name of the main investing parent(s), any joint venture partners, the date and location of initial investment into the affiliate, and a written description of the affiliate's main business line. For both the main Japanese investing firm and the affiliate, industry affiliation is determined by its main U.S. 4-digit SIC code at the time of investment into the particular affiliate. For the affiliate, the JOI's verbal description of the affiliate's main business line allows for a clear determination of the affiliate's activities at a 2-digit SIC level. For the few investments for which the JOI does not list an affiliate's main business line, the Polish Agency for Foreign Investment (PAIZ) provided this information.

Most Japanese firms that operate in Poland are engaged in sales and distribution activities of Japanese produced goods. Wholesale and retail trade affiliates comprise some 66 per cent of Japanese investments into Poland, while only a minority of affiliates is involved in manufacturing (18 per cent). The remaining firms operate in real estate ( 8 per cent), construction ( 6 per cent), and financial intermediation ( 2 per cent). The pattern of Japanese foreign direct investment differs significantly from the aggregate pattern of FDI made by all foreign firms operating in Poland, where sales and distribution activities and manufacturing account approximately for the same shares in the total number of foreign firms (32 per cent and 31 per cent, respectively). ${ }^{11}$

The spatial distribution of Japanese affiliates also differs significantly from the

\footnotetext{
${ }^{9}$ According to Polish government regulations, the CSO does not provide firm-level data to retain confidentiality (only aggregate investment data is available). As a result, we are forced to use the Toyo Keizai FDI data combined with the CSO's regional statistics data.

${ }^{10}$ Since January 16, 1999 Poland has a new system of local government and the previous 49 administrative units (voivodships) were replaced with 16 larger regions to correspond with the EU's NUTS-2 level classification. Consequently, no data on regional characteristics is available for the old smaller regions after this date. It is possible, however, to assign the old regions to the new bigger regions to create a time series for the 16 regions covering the entire sample period.
}

${ }^{11}$ See (CSO, 2002), The economic activity of firms with foreign capital participation in 2001. 
Table 1. Spatial distribution of foreign and Japanese firms within Poland in 2001

\begin{tabular}{lccccc}
\hline \multicolumn{1}{c}{ Region } & $\begin{array}{c}\text { Japanese } \\
\text { firms } \\
\text { (per cent) }\end{array}$ & $\begin{array}{c}\text { All foreign } \\
\text { firms } \\
\text { (per cent) }\end{array}$ & $\begin{array}{c}\text { Regional } \\
\text { GDP } \\
\text { (per cent) }\end{array}$ & $\begin{array}{c}\text { JDI/GDP } \\
\text { share } \\
\text { (ratio) }\end{array}$ & $\begin{array}{c}\text { FDI/GDP } \\
\text { share } \\
\text { (ratio) }\end{array}$ \\
\hline Dolnośląki & 4.0 & 10.5 & 7.9 & 0.507 & 1.334 \\
Kujawsko-pomorski & 0.0 & 2.6 & 4.8 & 0.000 & 0.542 \\
Lubelski & 0.0 & 2.0 & 4.0 & 0.000 & 0.494 \\
Lubuski & 0.0 & 4.2 & 2.4 & 0.000 & 1.738 \\
Lódzki & 2.0 & 4.6 & 6.3 & 0.319 & 0.735 \\
Małopolski & 2.0 & 5.5 & 7.4 & 0.269 & 0.737 \\
Mazowiecki & 72.0 & 29.8 & 19.6 & 3.680 & 1.521 \\
Opolski & 2.0 & 3.1 & 2.4 & 0.848 & 1.305 \\
Podkarpacki & 2.0 & 1.7 & 4.0 & 0.496 & 0.421 \\
Podlaski & 0.0 & 0.6 & 2.3 & 0.000 & 0.276 \\
Pomorski & 2.0 & 7.1 & 5.7 & 0.349 & 1.234 \\
Śląski & 10.0 & 10.0 & 13.9 & 0.718 & 0.721 \\
Świętokrzyski & 0.0 & 1.0 & 2.7 & 0.000 & 0.387 \\
Warmińsko-mazurski & 0.0 & 2.0 & 2.9 & 0.000 & 0.675 \\
Wielkopolski & 4.0 & 8.7 & 9.1 & 0.438 & 0.949 \\
Zachodnio-pomorski & 0.0 & 6.6 & 4.5 & 0.000 & 1.481 \\
Total & 100.0 & 100.0 & 100.0 & 1.000 & 1.000 \\
\hline Soul & & & &
\end{tabular}

Source: (CSO and Toyo Keizai, 2002)

distribution of all foreign affiliates. Japanese firms are more highly concentrated in the central (Mazowiecki) region than non-Japanese owned affiliates. This region, which includes the Polish capital of Warsaw and accounts for almost 20 per cent of Poland's GDP, is home to 72 per cent of all Japanese affiliates operating in Poland but only 30 per cent of all foreign affiliates operating in Poland (CSO, 2002). The second largest agglomeration of Japanese affiliates in Poland is in the Śląski region of the south, around the industrial city of Katowice. The remaining Japanese investment is somewhat evenly spread throughout the rest of country (see Table 1).

If we examine the location of Japanese FDI by affiliate industry, nearly 90 per cent of all wholesale and retail affiliates are located in the area surrounding Warsaw. In contrast, only 50 per cent of all Japanese manufacturing affiliates are located in the Warsaw area. Here, manufacturing affiliates are far more evenly spread out across the entire country, indicating the difference in motivation between manufacturing and wholesale/retail investment into the country. This result is not very surprising given that sales and distribution activities concentrate close to large markets and the Warsaw metropolitan area is the largest market 
within Poland and one of the largest in Central and Eastern Europe. For manufacturing affiliates, designed to service the entire European market and not just Poland itself, the location decision is somewhat different than that of the wholesale/retail investments.

To investigate the influences of the centripetal and centrifugal forces described in the previous section, we employ a vector of regional characteristics that takes into account economic size, agglomeration effects, labor market conditions, infrastructure, geographic location, and tax incentives. In addition to the regional characteristics, time effects for particular years of our sample are considered since we are using a pooled dataset. These effects are necessary to control for business cycle effects and policy changes during our sample period.

A region's economic size is measured by its GDP (expressed in the constant 1997 zloty). The GDP variable appears as a positive and significant FDI determinant in most previous empirical firm location studies. GDP can have both demand and supply interpretations as, on the demand side, GDP reflects a region's market size and thus the potential demand for host-market serving FDI (Broadman and Sun, 1997). On the supply side, multinationals create demand for non-tradable inputs whose supply is proportional to the size of a regional economic base (Head and Ries, 1996).

Agglomeration effects include urbanization economies, approximated with the percentage of population living in urban areas (URBAN), and industry- and servicespecific economies measured by employment shares in the secondary-sector (INDUSTRY) and tertiary-sector (SERVICE), respectively. ${ }^{12}$ The sign of urbanization variable (URBAN) cannot be a priori determined as it can positively and negatively affect firm location decisions. The impact of urbanization is positive when face-to-face communication and informational spillovers are important (Glickman and Woodward, 1988; Coughlin and Segev, 2000). However, urbanization may discourage foreign investors when it is associated with negative externalities such as congestion or pollution. Regional industry- and servicespecific economies (INDUSTRY, SERVICE) are expected to have a positive impact on the number of foreign firms in the region as it is frequently argued that higher regional specialization in industrial activities benefits investors in the form of industry specific base (Smith and Florida, 1994). A similar argument applies to specialization in services (Woodward, 1992; Guimarães et al., 2000).

\footnotetext{
${ }^{12}$ The secondary sector includes mainly manufacturing while the tertiary sector includes a multitude of service activities.
} 
Regional labor market characteristics include the average monthly wage (WAGE) expressed in constant 1997 prices, the unemployment rate (UNEMPLOY), and the number of college and university students per 100,000 inhabitants (EDUCATION). Previous empirical evidence in regard to the impact of labor market characteristics on FDI is mixed and it is not clear what coefficient signs should be expected (Guimarães et al., 2000). This is because while foreign investors display high sensitivity to international variations in labor costs, sensitivity with respect to regional differentials within a country is less pronounced. A host region's labor supply may have an impact on foreign firms' location decisions not in terms of input costs but through the quality of the skills of the labor force (Broadman and Sun, 1997). Also, while a high unemployment rate can indicate labor availability and thus have a dampening effect on wages (Coughlin and Segev, 2000), it can also signal less competitive conditions and a region's lower quality of life that discourages potential investors (Basile, 2002).

Infrastructure is captured with the total length of road (ROADS) and rail networks (RAILWAYS) (each expressed in kilometers), area (AREA) (expressed in squared kilometers), and dummy variables for the presence of at least one seaport (SEAPORT) and international airport (AIRPORT) within the region. Telecommunication density (TELECOMM) is approximated by the number of telephone subscribers per 100,000 inhabitants. Infrastructure variables are generally expected to positively influence the number of foreign firms as well-developed infrastructure signals higher regional productivity and increased firm profits. For AREA, its impact cannot be a priori determined as while a larger area possibly results in a lower infrastructure density (and thus lower regional productivity), size can also be treated as a proxy for the number of potential investment sites which positively impacts investment (Bartik, 1985).

To maintain consistency with the previous studies, fiscal incentives are captured with two measures: (1) a dummy variable for Special Economic Zones that were established in the second half of the 1990s (SEZ) and (2) a variable indicating the total number of established zones (SEZNUM). In October, 1994 the Polish parliament passed the Law on Special Economic Zones with the aim of

\footnotetext{
${ }^{13}$ In many zones the extent of the state aid was investment project specific and depended on the capital invested or the number of jobs created. Unfortunately, our dataset does not allow us to link individual firms with particular investment incentives.

${ }^{14}$ See, for example, Head and Ries (1996).
} 
Table 2. Regional characteristics definitions, expected signs, and summary statistics

\begin{tabular}{|c|c|c|c|c|c|c|}
\hline Variable & Definition & Expected sign & Min & Max & Mean & Std. Dev. \\
\hline GDP & $\begin{array}{l}\text { GDP at constant } 1997 \\
\text { prices (zloties) }\end{array}$ & Positive & $7,298,773$ & $9.48 \mathrm{e}+07$ & $2.54 \mathrm{e}+07$ & $1.90 \mathrm{e}+07$ \\
\hline Urbanization (URBAN) & $\begin{array}{l}\text { Urban population as per cent of total } \\
\text { population }\end{array}$ & 1 Cannot be a priori determined & 38.72 & 80.00 & 59.91 & 10.14 \\
\hline $\begin{array}{l}\text { Industry agglomeration } \\
(\text { INDUSTRY) }\end{array}$ & $\begin{array}{l}\text { Industry employment as per cent of } \\
\text { total employment }\end{array}$ & Positive & 12.10 & 42.10 & 23.60 & 5.94 \\
\hline $\begin{array}{l}\text { Service agglomeration } \\
(S E R V I C E)\end{array}$ & $\begin{array}{l}\text { Service employment as per cent of } \\
\text { total employment }\end{array}$ & Positive & 31.80 & 64.17 & 47.43 & 8.12 \\
\hline Wage (WAGE) & $\begin{array}{l}\text { Avg. monthly real wage (zloties) } \\
1997 \text { prices }\end{array}$ & Negative & 711.77 & 1932.99 & 975.63 & 228.42 \\
\hline Students (EDUCATION) & $\begin{array}{l}\text { College/university students per } \\
100,000 \text { inhabitants }\end{array}$ & Positive & 6635 & 312,418 & 54485.28 & 47819.22 \\
\hline Unemployment (UNEMPLOY) & Unemployment rate & Cannot be a priori determined & 3.85 & 29.05 & 13.87 & 4.59 \\
\hline $\begin{array}{l}\text { Road network } \\
(R O A D S)\end{array}$ & Total roads length (in km) & Positive & 7160 & 29,521 & 14803.88 & 5743.18 \\
\hline Railway lines (RAILWAYS) & $\begin{array}{l}\text { Operated railway network length } \\
\text { (in } \mathrm{km} \text { ) }\end{array}$ & Positive & 589.50 & 2612.82 & 1421.84 & 551.04 \\
\hline Area $(A R E A)$ & Total area $\left(\mathrm{km}^{2}\right)$ & Cannot be a priori determined & 8535 & 37,558 & 19542.81 & 7214.46 \\
\hline Seaport (SEAPORT) & 0/1 dummy & Positive & 0 & 1 & 0.13 & 0.33 \\
\hline $\begin{array}{l}\text { International airport } \\
(A I R P O R T)\end{array}$ & 0/1 dummy & Positive & 0 & 1 & 0.50 & 0.50 \\
\hline $\begin{array}{l}\text { Telecommunications } \\
\text { infrastructure (TELECOMM) }\end{array}$ & $\begin{array}{l}\text { Telephone subscribers per } 100,000 \\
\text { inhabitants }\end{array}$ & Positive & 5475 & 33,940 & 15864.98 & 6690.48 \\
\hline Capital (CAPITAL) & 0/1 dummy & Positive & 0 & 1 & 0.06 & 0.24 \\
\hline $\begin{array}{l}\text { Special Economic Zone } \\
\text { DUMMY }(S E Z)\end{array}$ & 0/1 dummy & Positive & 0 & 1 & 0.21 & 0.41 \\
\hline $\begin{array}{l}\text { Special Economic Zone } \\
\text { number (SEZNUM) }\end{array}$ & Number of zones in the region & Positive & 0 & 3 & 0.30 & 0.66 \\
\hline
\end{tabular}


accelerating economic development of selected regions of the country by offering geographically targeted fiscal incentives to investing firms. The first SEZ was established in 1995 in the Podkarpacki region and the next two in 1996 in the El ${ }^{1}$ ski and Podlaski regions. The process of establishing the zones continued until 1997 when an additional 14 SEZs were created (however, 2 never officially operated and were liquidated in 2001). Eventually, operational SEZ were located in 11 of the 16 Polish regions.

Poland's 1998 accession negotiations with the EU revealed that fiscal incentives offered within the SEZs did not comply with the EU Association Agreement. This agreement was signed by Poland in 1991 (and entered into force in 1994), significantly before the law on SEZs was created. Therefore, in 1998 Polish authorities agreed to not establish any new SEZs and initiated efforts to bring the financial aid granted in the zones into line with the EU acquis. As a result, different SEZs offered various investment incentives whose extent varied over the course of time. ${ }^{13}$ In the light of the difficulties associated with measuring the extent of the state aid in particular zones, we have decided to employ the more frequently used dummy variable approach to summarize all advantages offered by the zones in the region. ${ }^{14}$ To test the robustness of our results employing the dummy variable approach, we use the number of SEZs (SEZNUM) as the measure of fiscal incentives in the region.

Table 2 shows exact definitions of regional characteristics, summary statistics and their expected impact on Japanese firms' location decisions. To avoid potential simultaneity problems all explanatory variables come with a one-period lag.

\section{Estimation Results}

The estimation results are presented in the following manner: we begin by presenting estimation results from the baseline FDI location choice regressions used in many previous empirical studies and then proceed by investigating the robustness of these results using additional regional characteristics.

\section{A. Baseline specification}

We begin by estimating two count models: the Poisson and the negative binomial. However, we could not reject the equality of the alpha parameter with zero in the negative binomial model and, in all specifications, the likelihood ratio test rejected overdispersion in the pooled dataset. Therefore, as the Poisson model 
Table 3. Poisson model regression estimates on pooled dataset 1991-2001 (16 regions)

\begin{tabular}{|c|c|c|c|c|c|c|c|c|}
\hline Variable & (1) & (2) & (3) & (4) & (5) & (6) & (7) & (8) \\
\hline CONSTANT & $\begin{array}{c}-4.497 * * * \\
(7.47)\end{array}$ & $\begin{array}{c}-5.215^{* * *} \\
(7.79)\end{array}$ & $\begin{array}{c}-7.042 * * * \\
(5.85)\end{array}$ & $\begin{array}{c}-10.406 * * * \\
(5.76)\end{array}$ & $\begin{array}{c}-12.527 * * * \\
(4.37)\end{array}$ & $\begin{array}{c}-10.527 * * * \\
(3.49)\end{array}$ & $\begin{array}{c}-32.511 \\
(0.02)\end{array}$ & $\begin{array}{c}-12.354^{* * *} \\
(4.30)\end{array}$ \\
\hline GDP & $\begin{array}{c}4.58 \mathrm{e}-08^{* * * *} \\
(6.22)\end{array}$ & $\begin{array}{c}4.03 \mathrm{e}-08^{* * *} \\
(5.41)\end{array}$ & $\begin{array}{c}3.34 \mathrm{e}-08^{* * * *} \\
(2.78)\end{array}$ & $\begin{array}{l}2.14 \mathrm{e}-08^{* *} \\
(2.25)\end{array}$ & $\begin{array}{c}2.40 \mathrm{e}-08 \\
(1.22)\end{array}$ & $\begin{array}{c}1.18 \mathrm{e}-08 \\
(0.47)\end{array}$ & $\begin{array}{c}-4.87 \mathrm{e}-08 \\
(1.24)\end{array}$ & $\begin{array}{c}-2.51 \mathrm{e}-08 \\
(1.27)\end{array}$ \\
\hline WAGE & $\begin{array}{c}0.001 * * * \\
(3.06)\end{array}$ & $\begin{array}{c}0.001 * * \\
(2.53)\end{array}$ & $\begin{array}{l}0.001 \\
(1.56)\end{array}$ & $\begin{array}{c}0.001 * * * \\
(2.76)\end{array}$ & $\begin{array}{l}0.002 \\
(1.60)\end{array}$ & $\begin{array}{l}0.002 \\
(1.63)\end{array}$ & $\begin{array}{l}0.003 \\
(1.08)\end{array}$ & $\begin{array}{l}0.002 \\
(1.55)\end{array}$ \\
\hline EDUCATION & $\begin{array}{c}-0.039 * * * \\
(3.14)\end{array}$ & $\begin{array}{c}-0.098 * * * \\
(5.22)\end{array}$ & $\begin{array}{c}-0.090 * * * \\
(4.57)\end{array}$ & $\begin{array}{c}-0.107 * * * \\
(5.18)\end{array}$ & $\begin{array}{c}-0.139 * * * \\
(4.27)\end{array}$ & $\begin{array}{c}-0.104 * * * \\
(3.13)\end{array}$ & $\begin{array}{c}-0.161^{* *} \\
(2.27)\end{array}$ & $\begin{array}{c}-0.141 * * * \\
(4.84)\end{array}$ \\
\hline ROADS & $\begin{array}{c}1.13 \mathrm{e}-04 * * * \\
(2.64)\end{array}$ & $\begin{array}{c}1.56 \mathrm{e}-04 * * * \\
(2.63)\end{array}$ & $\begin{array}{c}1.40 \mathrm{e}-04^{* *} \\
(2.25)\end{array}$ & $\begin{array}{c}1.75 \mathrm{e}-04 * * * \\
(2.75)\end{array}$ & $\begin{array}{c}1.53 \mathrm{e}-04^{*} \\
(1.65)\end{array}$ & $\begin{array}{c}1.41 \mathrm{e}-04 \\
(1.54)\end{array}$ & $\begin{array}{c}3.91 \mathrm{e}-04^{* *} \\
(2.15)\end{array}$ & $\begin{array}{c}1.45 \mathrm{e}-04 \\
(1.62)\end{array}$ \\
\hline RAILWAYS & $\begin{array}{c}-0.001 * * * \\
(3.78)\end{array}$ & $\begin{array}{c}-0.002 * * * \\
(5.27)\end{array}$ & $\begin{array}{c}-0.002 * * * \\
(5.05)\end{array}$ & $\begin{array}{c}-0.003 * * * \\
(5.54)\end{array}$ & $\begin{array}{c}-0.004 * * * \\
(4.19)\end{array}$ & $\begin{array}{c}-0.002^{* *} \\
(2.32)\end{array}$ & $\begin{array}{c}-0.003 * \\
(1.67)\end{array}$ & $\begin{array}{c}-0.004^{* * * *} \\
(4.21)\end{array}$ \\
\hline AREA & $\begin{array}{c}6.80 \mathrm{e}-06^{* * *} \\
(3.90)\end{array}$ & $\begin{array}{c}3.4 \mathrm{e}-05 \\
(1.54)\end{array}$ & $\begin{array}{c}5.47 \mathrm{e}-05^{* *} \\
(2.16)\end{array}$ & $\begin{array}{c}9.83 \mathrm{e}-05 * * * \\
(3.27)\end{array}$ & $\begin{array}{c}1.48 \mathrm{e}-04 * * * \\
(2.77)\end{array}$ & $\begin{array}{c}4.93 \mathrm{e}-05 \\
(0.74)\end{array}$ & $\begin{array}{c}-6.98 \mathrm{e}-06 \\
(0.07)\end{array}$ & $\begin{array}{c}1.49 \mathrm{e}-04 * * * \\
(2.89)\end{array}$ \\
\hline SEZ & $\begin{array}{c}0.859 * * * \\
(3.27)\end{array}$ & $\begin{array}{l}0.162 \\
(0.51)\end{array}$ & $\begin{array}{l}0.126 \\
(0.38)\end{array}$ & $\begin{array}{l}0.164 \\
(0.49)\end{array}$ & $\begin{array}{l}0.165 \\
(0.38)\end{array}$ & $\begin{array}{l}-0.241 \\
(0.59)\end{array}$ & $\begin{array}{c}-1.852 * * * \\
(2.64)\end{array}$ & \\
\hline SEZNUM & . & $\cdot$ & $\cdot$ & $\cdot$ & $\cdot$ & . & $\cdot$ & $\begin{array}{l}-0.131 \\
(0.61)\end{array}$ \\
\hline TELECOMM & . & $\begin{array}{c}1.44 \mathrm{e}-04 * * * \\
(3.85)\end{array}$ & $\begin{array}{c}1.50 \mathrm{e}-04 * * * \\
(3.64)\end{array}$ & $\begin{array}{c}1.59 \mathrm{e}-04 * * * \\
(3.84)\end{array}$ & $\begin{array}{c}8.09 \mathrm{e}-05 \\
(0.81)\end{array}$ & $\begin{array}{c}1.08 \mathrm{e}-04 \\
(1.05)\end{array}$ & $\begin{array}{c}8.96 \mathrm{e}-05 \\
(0.46)\end{array}$ & $\begin{array}{c}-8.72 \mathrm{e}-05 \\
(0.88)\end{array}$ \\
\hline AIRPORT & . & $\begin{array}{c}1.274^{* *} \\
(2.51)\end{array}$ & $\begin{array}{c}1.871^{* * *} \\
(3.18)\end{array}$ & $\begin{array}{c}1.753 * * * \\
(3.07)\end{array}$ & $\begin{array}{c}2.087^{* * *} * \\
(3.12)\end{array}$ & $\begin{array}{c}2.207 * * * \\
(3.26)\end{array}$ & $\begin{array}{c}2.454^{* * *} \\
(1.97)\end{array}$ & $\begin{array}{c}2.139 * * * \\
(3.18)\end{array}$ \\
\hline UNEMPLOY & . & (a) & $\begin{array}{l}0.027 \\
(0.79)\end{array}$ & . & . & . & . & . \\
\hline URBAN & . & . & $\begin{array}{l}0.040^{*} \\
(1.80)\end{array}$ & $\cdot$ & $\cdot$ & $\cdot$ & . & $\cdot$ \\
\hline SERVICE & . & . & (1.00) & $\begin{array}{c}0.063 * * \\
(2.30)\end{array}$ & $\begin{array}{c}0.095 * * \\
(2.00)\end{array}$ & $\begin{array}{l}0.024 \\
(0.42)\end{array}$ & $\begin{array}{l}0.178^{*} \\
(1.72)\end{array}$ & $\begin{array}{c}0.092 * * \\
(2.05)\end{array}$ \\
\hline INDUSTRY & . & . & . & $\begin{array}{c}0.107 * * * \\
(3.15)\end{array}$ & $\begin{array}{l}0.134^{*} \\
(1.88)\end{array}$ & $\begin{array}{c}0.165^{* * *} \\
(2.22)\end{array}$ & $\begin{array}{l}0.132 \\
(0.91)\end{array}$ & $\begin{array}{l}0.131^{*} \\
(1.85)\end{array}$ \\
\hline CAPITAL & & & & (c) & . & $\begin{array}{c}3.107 * * \\
(2.39)\end{array}$ & & \\
\hline Time effects & NO & NO & NO & NO & YES & YES & YES & YES \\
\hline PseudoR ${ }^{2}$ & 0.804 & 0.829 & 0.833 & 0.836 & 0.843 & 0.847 & 0.588 & 0.843 \\
\hline Loglikelihood & -142.47 & -124.21 & -121.50 & -118.87 & -114.00 & -111.10 & -42.80 & -113.89 \\
\hline
\end{tabular}

Note: Z-stats in parenthesis. ***, **,* - significant at the 1 per cent, 5 per cent, and 10 per cent, respectively. 
and the negative binomial model estimation results were identical, we limit ourselves to the description of the Poisson model results only.

The baseline specification estimates presented in column (1) of Table 4 conditions the dummy for special economic zones on the following regional characteristics: GDP, real average wage rate, number of college and university students per 100,000 inhabitants, total road network length, operated railway network length, and total area. Such a regression generates a high value of pseudo- $\mathrm{R}^{2}(0.804)$ and all explanatory variables appear statistically significant at the 1-per cent level. ${ }^{15}$ In regard to the SEZ dummy, we find that with the current set of region-specific explanatory variables, SEZs have a positive and significant impact on FDI location choice. Hence, we argue that our results are mostly in line with the results obtained by other authors and draw similar conclusion as to the success of this approach and the significance of the SEZ dummy variable and other explanatory variables. These conclusions, however, change dramatically when we subject this specification to a number of sensitivity tests related to the choice of explanatory variables that constitute the conditioning set.

\section{B. Extended set of region-specific characteristics}

In this section we focus on the impact of the SEZ dummy variable when additional region-specific characteristics are included in the conditioning set. In column (2) we extend our specification to include a number of additional infrastructure variables: the telecommunications infrastructure density variable (TELECOMM) and separate dummy variables for the presence of seaports $(S E A P O R T)$ and international airports (AIRPORT) within the region. Our

\footnotetext{
${ }^{15}$ The negative signs associated with the EDUCATION and RAILWAYS are somewhat puzzling. In addition to tertiary education, we also test a model (results not reported here) that included a secondary school enrollment index; however, this variable was not statistically significant. As a result, it may be that Japanese investors prefer workers with vocational education. Alternatively, one could also speculate that Poland's very inflexible labor market during this period contributed to many students continuing their education instead of entering the labor force; as a result, EDUCATION is a signal of poor economic conditions, and thus decreases the likelihood of investment into the area. We expect this inflexibility to be eliminated as Poland's economic transition continues, and thus EDUCATION would serve as a measure of human capital (and positively impact FDI location choice). In regard to RAILWAYS, foreign firms may prefer access to modern transportation infrastructure such as highways and not railways that are used mainly for transporting bulk commodities that Japanese firms operating in Poland do not produce. An alternative explanation is that the regions with extensive railway networks are most likely associated with declining industrial areas that do not serve as attractive investment locations.
} 
regression results indicate that each variable appears statistically significant (although at different significance levels). However, by using this extended set of region-specific characteristics, the SEZ variable loses its statistical significance. This result suggests that the previous significance of the SEZ variable could be explained on the grounds that the SEZ variable represented both the SEZ and some other regional effects. Once these regional effects are independently included in the sample, the SEZ dummy variable only captures the SEZ effect. In this particular case, it appears that infrastructure variables are linked to the SEZ variable, as SEZs were established mostly in regions with developed infrastructure. Additionally, most of the other explanatory variables maintain their qualitative impact on investment, with the exception being the area variable that loses its previous statistical significance.

In column (3) we broaden the specification of the estimating equation by adding the unemployment rate and the share of urban population - one of possible measures of agglomeration economies. In doing so, we find the unemployment rate to not be statistically significant while the urbanization variable is only statistically significant at the 10-percent level. Once again, the SEZ dummy remains statistically not significant. Compared to the estimation results presented in column (2), the airport variable becomes statistically significant at the 1-percent level and the area variable at the 5-percent level, while the wage and seaport variables lose their statistical significance. ${ }^{16}$

In column (4) we account for the importance of industry and service related agglomeration economies. ${ }^{17}$ Again, the SEZ variable remains statistically insignificant. The share of industry in regional employment is statistically significant at the 1-per cent level, while the share of the service sector is statistically significant at the 5-per cent level. These results suggest the importance of links between the firms in the location decision. The GDP variable becomes statistically significant only at the 5-per cent level, the area, roads and wage variables are significant at the 1-percent level, while the seaport variable loses its statistical significance.

In their comprehensive survey article on Japanese FDI in Central and Eastern Europe, Cieślik and Ryan (2002) note that the yearly inflow of the Japanese FDI

\footnotetext{
${ }^{16}$ This may be due to the fact that more urbanized areas typically offer higher wage rates.

${ }^{17}$ In a previous version of this article, we simultaneously included the urbanization and unemployment variables in a regression equation. However, neither variable was statistically significant when industryand service-related agglomeration variables were present.
} 
into Poland declined after 1997. In column (5) we control for time effects by adding dummy variables for particular years. However, the inclusion of the time dummies does not affect our results concerning the significance of the SEZ dummy variable as it remains statistically not significant. We do see, however, that the GDP, WAGE, and TELECOMM variables lose their significance, as these are correlated with the expansion of the Polish market (and, thus, the time trend).

As previously noted, most Japanese affiliates are located in the Mazowiecki (central) region in the area of and around Warsaw. To determine how our previous results are affected by this geographic clustering, in column (6) we include the dummy variable CAPITAL that takes the value one if the region is the Mazowiecki region and zero otherwise. Our estimation results indicate that the CAPITAL dummy has a positive sign and is statistically significant at the 5-per cent level, confirming the importance of the Warsaw area market for the Japanese investors. It appears that, in terms of investment counts, Japanese FDI primarily services the domestic market, as a majority of investment is into services rather than manufacturing. ${ }^{18}$ By including the CAPITAL dummy variable, we find that the ROADS, AREA, and SERVICE variables become statistically not significant. This is not surprising, as the Mazowiecki region is the largest Polish administrative area and is also home to the most well developed road network as well as the country's main service hub. Once again, the SEZ variable remains not statistically significant.

Unlike the sale and distribution activities that dominate investments in the service sector (investments geared toward servicing the domestic market), manufacturing affiliates tend to spread more evenly across the country in order to serve better the entire European market. Therefore, instead of using the entire sample of all Japanese firms, in column (7) we present estimation results obtained only for the firms engaged in manufacturing. Compared to our previous results, the SEZ dummy variable becomes statistically significant at the 1-per cent level. However, it appears with a negative sign suggesting that Japanese manufacturing firms generally prefer to invest in the regions different from those where the SEZs were established. ${ }^{19}$ This result appears to indicate that the tax incentives granted

\footnotetext{
${ }^{18}$ In terms of investment capital, we expect the opposite to be true; that is, while the service affiliates primarily located in the central region outnumber the manufacturing affiliates primarily located in the southern border regions, manufacturing affiliates are much larger in size (in terms of invested capital).

${ }^{19}$ In the baseline specification that parallels the specification in column (1), the SEZ dummy variable was not statistically significant. In other specifications that parallel columns (2)-(4), this variable always appeared with the negative sign and it was either not statistically significant or significant only at the 5-per cent level.
} 
Japanese investors did not outweigh the fact that these SEZs are located in areas not conducive for manufacturing operations. Thus, since these SEZs were typically created in economically depressed areas in the hopes of attracting these investments, their creation actually serves to identify locations in which Japanese manufacturing investors do not wish to invest.

Note also in the manufacturing-only regression that the qualitative results associated with the variables in the conditioning set change little. The notable exception is the road infrastructure variable that becomes statistically significant at the 5-per cent level. This confirms that the road network for the location of manufacturing firms is of greater importance than for firms operating in the service sector.

Finally, to further test the robustness of our results we use the alternative measure of the extent of the state aid granted foreign investors - the number of special economic zones in the region (SEZNUM) ${ }^{20}$ The estimation results when the number of SEZs is used instead of a dummy variable are presented in column (8). As in columns (2)-(7), where the SEZ dummy variable is used, this SEZNUM measure is not statistically significant (the estimates of other variables in the conditioning set change little compared to specifications where the SEZ dummy was used). ${ }^{21}$ As such, we argue that the number of established SEZs is also not an accurate measure of determining state aid to foreign investors. For example, in 2001 some of the zones merged although the extent of the aid within the zones did not change. ${ }^{22}$ Clearly, there is nothing to suggest the correlation between the number of SEZs a country creates and the actual aid granted to firms investing within a given SEZ.

\footnotetext{
${ }^{20}$ For studies that examine the number of SEZs created within a country, see Cheng and Kwan (2000) and Makabenta (2002).

${ }^{21}$ In results not reported here (and available by request from the authors), specifications (1)-(8) were reestimated using also the number of previously established Japanese firms in the region; however, this variable was not statistically significant. In addition, we employ the CSO data and test for the presence of agglomeration economies related to previously established non-Japanese foreign investors. In specification (1) this variable significantly (at the 1-per cent level) influenced location choice. However, when the additional region-specific variables were added, this variable's statistical significance disappeared. Therefore, there appears no significant evidence for the existence of linkages between Japanese and other foreign investors at the regional level.

${ }^{22}$ This merging of SEZs does not apply to our study (as we use lagged independent variables), this speaks to the problem of using the number of SEZs as a measure of state aid. One must, however, be aware that Polish SEZs are not homogeneous entities concentrated in space but consist of a number of geographically disperse sub-zones located also in regions different from location of their managing offices.
} 


\section{Conclusion}

This article investigates the robustness of previous empirical findings that suggest geographically targeted investment incentives (Special Economic Zones) significantly influence inward FDI into that particular region. To do so, we combine data on Japanese multinational activity within Poland during the period 1991-2001 with an extensive dataset on Polish regional characteristics. We chose Poland as the FDI source for several reasons: (i) it broadly mimics China (the FDI host in most SEZ studies) as they both have made significant investment into creating FDI-attracting SEZs, (ii) they are emerging FDI-hosts with significantly transitioning economies, and (iii) both receive significant Japanese FDI designed to service both the domestic and geographically regional markets. However, given its wealth of Polish region-specific data, Poland serves as an excellent test to determine whether naming a region an SEZ actually attract additional inward FDI.

Our findings concerning the impact of particular regional characteristics on the number of Japanese firms in Poland are broadly consistent with the previous empirical literature on FDI location determinants. However, a number of important differences can be identified. We find that there are very few variables that remain statistically significant across all estimating equations. For example, several infrastructure variables lose their significance once we control for time effects, as infrastructure growth increases with Poland's transition toward EU membership in 2004. Most prominent in this list of equation-specific effects are the special economic zones that are often measured imperfectly as a dummy variable (for the presence of a zone in a particular region) or by the total number of established zones. Initially a highly significant FDI influence, SEZs lose their statistical significance in subsequent regressions that control for the extended set of regional characteristics. That is, once we extend the traditional set of location-specific characteristics to take advantage of the more in-depth Polish dataset, we find that SEZs as measured in previous studies do not serve to attract Japanese FDI. This result may not be that surprising, as tax incentives are not likely to influence Japanese MNEs given Japan's status as a high tax-credit country (52 per cent). As a result, corporate taxes may not play a significant role in their location decision (Hines, 1996). However, our results do contrast previous empirical work that indicates Japanese MNEs positively respond to SEZ formation (e.g., Fung et al. (2002)).

Thus, our results suggest a problem with the use of simple SEZ measures such 
as dummy variables or the number of zones as the sole indicators of aid given to firms investing in these areas. Given the lack of robustness of our SEZ variable across estimation equations, and the now apparent lack of robustness across FDIhosts with operational SEZs in place, we conclude that one must be quite cautious in making policy recommendations based on regression analysis employing SEZ dummy variables and incomplete sets of regional characteristics.

Clearly, more work must be done to identify the benefits of SEZ formation in attracting inward FDI. Future work should extend beyond criticizing the use of imperfect SEZ proxies and try to establish a measure that better captures the investment incentives offered by the SEZs. The ideal solution would be the use of detailed data on the incentives available to construct the first principal component of all the incentives and include it in the estimating equation instead of following the either the dummy variable or the number of zones approaches. This principal component approach would have the advantage of being a continuous variable which reflects differences in the degree by which the regions differ with respect to investment incentives, allowing for a dynamic characterization of the actual state aid offered foreign investors.

\section{Acknowledgements}

The authors wish to thank the anonymous referees and the participants of the European Economic and Finance Society conference.

Received 1 February 2004, Accepted 1 July 2004

\section{References}

Abdel-Rahman, H.M. (1988) Product Differentiation, Monopolistic Competition and City Size, Regional Science and Urban Economics, 18, 69-86.

Abdel-Rahman, H.M. (1990) Agglomeration Economies, Types and Sizes of Cities, Journal of Urban Economics, 27, 25-45.

Kearney, A.T. (2003) Foreign Direct Investment Confidence Index, 2003, Global Business

Policy Council, Alexandria, VA.

Bartik, T. (1985) Business Location Decisions in the United States: Estimates of the Effects of Unionization, Taxes, and Other Characteristics of States, Journal of Business Economic Statistics, 3, 14-22.

Basile, R. (2002) Acquisition Versus Greenfield Investment: The Location of Foreign 
Manufacturers in Italy, Institute for Studies and Economic Analyses Discussion Paper, Rome.

Broadman, H.G. and Sun, X. (1997) The Distribution of Foreign Direct Investment in China, World Economy, 20, 339-361.

Carlton, D. (1983) The Location and Employment Choices of New Firms: An Econometric Model with Discrete and Continuous Endogenous Variables, Review of Economics and Statistics, 65, 440-449.

Carod J.M.A. (2002) Determinants of industrial location: An application for Catalan municipalities, Working Paper, Rovira i Virgilli University.

Carstensen, K. and Toubal F. (2003) Foreign Direct Investment in Central and East European Countries: A Dynamic Panel Analysis, Kiel Working Paper No. 1143.

Central Statistical Office, (2002) The Activity of Firms with Foreign Capital Participation in 2001, Zakład Wydawnictw Statystycznych, Warsaw.

Cheng, L.K. and Kwan, Y.K. (2000), What are the Determinants of the Location of Foreign Direct Investment? The Chinese Experience, Journal of International Economics, 51, 379-400.

Cieślik, A. and Ryan, M. (2002) Characterizing Japanese Direct Investment in Central and Eastern Europe: A Firm-level Investigation of Stylized Facts and Investment Characteristics, Post-Communist Economies, 14, 509-527.

Cieślik, A. and Ryan, M. (2004) Explaining Japanese Direct Investment Flows into an Enlarged Europe: A Comparison of Gravity and Economic Potential Approaches, Journal of the Japanese and International Economies, 18, 12-37.

Coughlin, C.C. and Segev, E. (2000) Location Determinants of New Foreign-owned Manufacturing Plants, Journal of Regional Science, 40, 323-351.

Devereux, M.P. and Griffith, R. (1998) Taxes and the Location of Production: Evidence from a Panel of US Multinationals, Journal of Public Economics, 68, 335-367.

Friedman, J., Gerlowski, D.A. and Silberman, J. (1992) What Attracts Foreign Multinational Corporations? Evidence from Branch Plant Location in the United States, Journal of Regional Science, 32, 403-418.

Fujita, M. (1988) A Monopolistic Competition Model of Spatial Agglomeration: Differentiated Product Approach, Regional Science and Urban Economics, 18, 87-124. Fujita, M. and Thisse, J.F. (2002) Economics of Agglomeration: Cities, Industrial Location and Regional Growth, Cambridge University Press, Cambridge.

Fung, K.C., Iizaka, H. and Parker, S. (2002) Determinants of U.S. and Japanese Direct Investment in China, Journal of Comparative Economics, 30, 567-578.

Glickman, N.J. and Woodward, D.P. (1988) The Location of Foreign Direct Investment in the United States: Patterns and Determinants, International Regional Science Review, 11, 137-154.

Guimarães, P., Figueiredo, O. and Woodward, D. (2000) Agglomeration and the Location of Foreign Direct Investment in Portugal, Journal of Urban Economics, 47, 115-135.

Head, K., Ries, J., Swenson, D. (1995) Agglomeration Benefits and Location Choice: Evidence from Japanese Manufacturing Investments in the United States, Journal of 
International Economics, 38, 223-247.

Head, K. and Ries, J. (1996) Inter-City Competition for Foreign Investment: Static and Dynamic Effects of China's Incentive Areas, Journal of Urban Economics, 40, 38-60.

Head, K., Ries, J. and Swenson, D. (1999) Attracting Foreign Manufacturing: Investment Promotion and Agglomeration, Regional Science and Urban Economics, 29, 197-218. Hines, J. (1996) Altered States: Taxes and the Location of Foreign Direct Investment in America, American Economic Review, 86, 1076-1094.

Holland D., Barrell R., Dury K., Byrne J. and Hurst I. (2001) The Determinants and the Impact of Foreign Direct Investment in Central and Eastern Europe: A Comparison of Survey and Econometric Evidence, Transnational Corporations, 9, 163-212

Krugman, P. (1991a) Geography and Trade, MIT Press, Cambridge MA.

Krugman, P. (1991b) Increasing Returns and Economic Geography, Journal of Political Economy, 99, 483-499.

Krugman, P. (1996) Urban Concentration: The Role of Increasing Returns and Transport Costs, International Regional Science Review, 19, 5-30.

Krugman, P. (1998) What's New About the New Economic Geography?, Oxford Review of Economic Policy, 14, 7-17.

Luger, M. and Shetty, S. (1985) Determinants of Foreign Plant Start-ups in the United States: Lessons for Policy Makers in the Southeast, Vanderbilt Journal of Transnational Law, 18, 223-245.

Makabenta, M.P. (2002) FDI Location and Special Economic Zones in the Phillipines, Review of Urban and Regional Development Studies, 14, 59-77.

Markusen J.R., (2002), Multinational Firms and the Theory of International Trade, MIT Press. Mayer, T. and Disdier A.C. (2003) How Different is Eastern Europe? Structure and Determinants of Location Choices by French Firms in Eastern and Western Europe. CEPII Working Paper No. 2003-13.

Mintz, J. (1990) Corporate Tax Holidays and Investment, World Bank Economic Review, Washington D.C.

Rivera-Batiz, F. (1988) Increasing Returns, Monopolistic Competition, and Agglomeration Economies in Consumption and Production, Regional Science and Urban Economics, 18, 125-153.

Schweinberger, A.G. (2003) Special Economic Zones in Developing and/or Transition Countries: A Policy Proposal, Review of International Economics, 11, 619-629.

Smith, D.F. and Florida, R. (1994) Agglomeration and Industrial Location: An Econometric Analysis of Japanese-affiliated Manufacturing Establishments in Automotive-related Industries, Journal of Urban Economics, 36, 23-41.

Wells, L. (1986) Investment Incentives: An Unnecessary Debate, The Center on Transnational Corporations Reporter, United Nations, Geneva.

Woodward, D.P. (1992) Locational Determinants of Japanese Manufacturing Start-ups in the United States, Southern Economic Journal, 58, 690-708.

UNCTAD, (2002) World Investment Report, United Nations, New York. 